\title{
Combustion Characteristics of Diesel Engine Using Producer Gas and Blends of Jatropha Methyl Ester with Diesel in Mixed Fuel Mode
}

\author{
Hifjur Raheman ${ }^{a^{*}}$, Debasish Padhee ${ }^{b}$ \\ ${ }^{a}$ Agricultural and Food Engineering Department, Indian Institute of Technology, Kharagpur India \\ 'Indiara Gandhi Agricultural University, Raipur, India
}

\begin{abstract}
An experimental investigation was performed to study the combustion characteristics of diesel engine fuelled with producer gas-biodiesel in dual fuel mode. Three different fuel blends of Jatropha methyl ester with high speed diesel (HSD) (B10, B20) and B100 were used with producer gas obtained from the gasification of briquettes made from de-oiled Jatropha seed cake. The increments in load on the engine increased the brake thermal efficiency, exhaust gas temperature and lowered the brake specific energy consumption. The ignition delays in dual-fuel mode of operation for both the fuels were longer than for single-fuel mode of operation. Combustion pressure and heat release rate (HRR) patterns at different engine loads were found to be similar for biodiesel and HSD. In dual-fuel mode, the peak pressure and HRR for producer gas-biodiesel dual-fuel were slightly lower than those of producer gas-diesel combustion at full load condition. Significantly lower NOx emissions were obtained under the dual fuel mode of operation for both pilot fuels compared to the single-fuel mode especially HSD under all test conditions.
\end{abstract}

Keywords: Biodiesel, Combustion characteristics, Dual fuel mode, Ignition delay, Producer gas

Article History: Received June 19, 2014; Received in revised form August 09, 2014; Accepted October 12, $2014 ;$ Available online

How to Cite This Article: Raheman, H \&Padhee,D. (2014) Combustion Characteristics of Diesel Engine Using Producer Gas and Blends of Jatropha Methyl Ester with Diesel in Mixed Fuel Mode. Int. Journal of Renewable Energy Development, 3(3), $228-235$.

http://dx.doi.org/10.14710/ijred.3.3.228-235

\section{Introduction}

On the context of rising prices of fossil fuels and growing climate change vegetable oils have come up as a promising source of biofuel. The vegetable oils due to their high density and viscosity cannot be used in unmodified diesel engines, so they are used in esterified (biodiesel) forms. But availability of vegetable oil is important for replacing fossil fuels. In order to reduce dependency on vegetable oil or on a particular fuel, dual fuel mode of operating the engine may be encouraged. Use of gaseous fuel with liquid fuel mode is one such propositions.
There has been a lot of research on combustion of biodiesel, performance and emissions of diesel engine with biodiesel (Alfuso et al. 1993, Raheman \& Phadatare 2004, Usta 2005, Deshmukh, \& Bhuyar 2009, Buyukkay 2010). From these previous studies it was reported that the engine fueled with biodiesel blends gives better performance with reduction in $\mathrm{HC}$ and $\mathrm{CO}$ emissions and increase in NOx emissions. Many researchers have studied the combustion and emission characteristics of the dual-fuel engines fueled with gaseous-liquid fuels. Banapurmath et al. (2008) tested a single cylinder, four stroke direct injection diesel engine with producer gas and honge oil and its methyl ester (HOME) in dual fuel

${ }^{*}$ Corresponding Author: +91-322283160; fax : +9132222822440

Email:hifjur@agfe.iitkgp.ernet.in 
mode and reported a slight reduction in thermal efficiency and increased smoke, HC and CO levels. Also HOME-producer gas operation showed improvement in heat release rate compared to neat honge oil-producer gas dual fuel operation. Mustafi and Raine (2008) experimentally investigated the exhaust emission characteristics of a direct injection (DI) diesel engine operated with natural gas or biogas-diesel dual-fuels. Their study showed that stable engine operation was possible with natural gas (NG) and biogas fueling without any modifications to either the engine or its operation, and that the particulate matter (about 70\% by mass) and NOx emissions (maximum of $37 \%$ by mass) of dual-fueling were much lesser than those of diesel fueling operating under the same condition. Maji et al. (2008) investigated the application of compressed natural gas (CNG) in reducing the noise level, specific fuel consumption, and NOx emissions. However, the unburned hydrocarbons (UHC) increased in the dualfuel mode with a substitution of CNG for $75 \%$ of the diesel fuel. Jie et al. (2003) investigated the influence of the CNG ratio, the advance of the pilot injection for diesel fuel and the intake temperature on the combustion process, emissions, and engine performance of an engine in dual fuel mode. Yoon and Lee (2011) performed an experimental investigation to study the influence of dual-fuel (biogas-biodiesel) combustion characteristics on the exhaust emissions and combustion performance in a diesel engine. The results of this study showed that in dual-fuel mode, the peak pressure and heat release for biogas-biodiesel were slightly lower compared to biogas-diesel at low load but at higher load, biogas-biodiesel combustion exhibited the slightly higher peak pressure, rate of heat release (ROHR) and indicated mean effective pressure (IMEP) than those of biogas-diesel. Also, the ignition delay for biogas-biodiesel indicated shortened trends compared to ultra low sulphur diesel (ULSD) dualfueling due to the higher cetane number (CN) of biodiesel. Significantly lower $\mathrm{NO}_{\mathrm{x}}$ emissions were emitted under dual-fuel operation for both cases of pilot fuels compared to single-fuel mode at all engine loadings. Also, biogas-biodiesel provided superior performance in reductions of soot emissions due to the absence of aromatics, the low sulfur, and oxygen contents for biodiesel.

Among the gaseous fuel producer gas is one which is produced by the oxidation and reduction reactions of biomass leading to typical products hydrogen, carbon dioxide, carbon monoxide, methane, some higher hydrocarbons, water vapour and rest nitrogen in proportions depending on the feedstock properties and reactant used. In remote rural areas where accessibility to fossil fuel is difficult, fuels derived from biomass are to be encouraged. With this in mind an attempt was made to study combustion performance of the diesel engine in dual fuel mode of operation using producer gas and biodiesel.

\section{Experimental setup and procedure}

\subsection{Experimental setup}

A single cylinder, four stroke direct injection diesel engine with the specifications as shown in Table 1 was selected to operate with producer gas and biodiesel in dual fuel mode. Producer gas was introduced to the intake manifold through a mixing chamber before entering the combustion chamber. Producer gas was passed through a rotameter that measured the flow rate of the gas and a fine control valve was fitted in the flow line to adjust the flow rate of gas inducted to the mixing chamber. At each load, the producer gas was introduced at the flow rate of $200 \mathrm{lpm}$.

Table 1

Test engine specifications

\begin{tabular}{ll}
\hline \multicolumn{1}{c}{ Items } & \multicolumn{1}{c}{ Specifications } \\
\hline Make and model & Field Marshal - GF3BMG \\
Rated power output & $7.5 \mathrm{hp}(5.6 \mathrm{~kW})$ \\
Rated speed (constant) & $1500 \mathrm{rpm}$ \\
Bore $\times$ Stroke & $87.5 \mathrm{~mm} \times 110 \mathrm{~mm}$ \\
Compression ratio & $17: 1$ \\
Fuel injection system & In-line, direct injection \\
Method of cooling & Water cooling \\
\hline
\end{tabular}

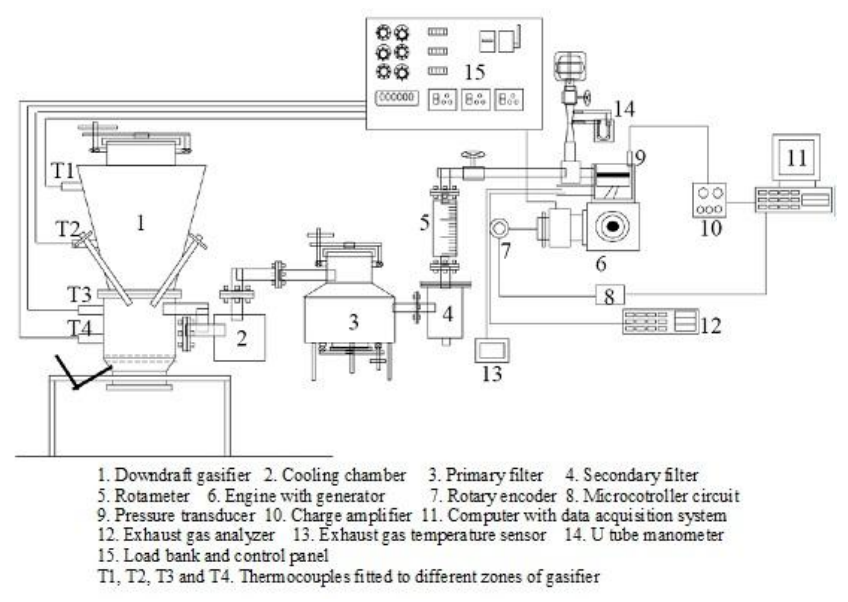

Fig. 1 Experimental setup.

Figure 1 shows the schematic of the experimental setup. The engine was coupled to an electric generator of 5 KVA capacity and it was loaded by load bank consisting of electric heaters and bulbs to apply different engine loads. Engine speed was measured by a digital tachometer with a resolution of $1 \mathrm{rpm}$. Incylinder pressure was measured using a Kistler watercooled piezo electric pressure transducer which was mounted on the cylinder head and was sampled every one degree crank angle. Crankshaft position was obtained using a rotary encoder to determine cylinder gas pressure as a function of crank angle. The heat release rate $(\mathrm{Q})$ was calculated from simplified approach shown in Eq. (1), which was derived from the first law of thermodynamics (Heywood 1988). 


$$
Q_{n}=\frac{1}{(\gamma-1)}\left[\gamma P \frac{d V}{d \theta}+V \frac{d P}{d \theta}\right]
$$

where:

- $\gamma$ is the ratio of specific heats which was taken as 1.35 ,

- $\theta$ is the crank angle,

- $\mathrm{P}$ is the cylinder gas pressure, and

- $\mathrm{V}$ is the cylinder volume.

The cylinder volume was calculated from the geometry as a function of the crank position.

A Chromel-Alumel thermocouple with a digital display meter was used to measure the exhaust gas temperature. An Indus make online exhaust gas analyzer was used to measure the carbon monoxide (CO), carbon dioxide $\left(\mathrm{CO}_{2}\right)$, hydrocarbon emission ( $\left.\mathrm{HC}\right)$ and nitrous oxides $\left(\mathrm{NO}_{\mathrm{x}}\right)$. The engine was run at a constant speed of $1500 \mathrm{rpm}$ and variable load of $25 \%$, $50 \%, 75 \%$ and $100 \%$ of maximum load. The fuel consumption was measured by gravimetric method with a graduated cylinder that having a total volume of $500 \mathrm{~cm} 3$ was previously filled with fuel and, while the engine was operated in the prescribed conditions, graduated cylinder was opened and a record of the time required for the given amount of fuel to be consumed was obtained. After allowing the engine to reach the steady state conditions, the following parameters were measured and recorded: fuel consumption, exhaust gas temperature, torque applied and cylinder pressure. This procedure was repeated for different loads.

Table 2

Fuel properties of jatropha oil, blends of jatropha methyl ester

\begin{tabular}{llllll}
\hline Properties & HSD & $\begin{array}{l}\text { Jatropha } \\
\text { oil }\end{array}$ & B10 & B20 & B100 \\
\hline Specific gravity & 0.812 & 0.896 & 0.821 & 0.825 & 0.866 \\
$\begin{array}{l}\text { Kinematic viscosity } \\
\left(\mathrm{mm}^{2} / \mathrm{s}\right)\end{array}$ & 2.60 & 20.69 & 3.39 & 4.63 & 9.60 \\
$\begin{array}{l}\text { Calorific value } \\
(\mathrm{M}) / \mathrm{kg})\end{array}$ & 42.4 & 36.53 & 40.848 & 39.54 & 36.61 \\
& & & & & \\
Flash point $\left({ }^{\circ} \mathrm{C}\right)$ & 52 & 212 & 64 & 82 & 166 \\
\hline
\end{tabular}

\subsection{Test fuels}

The jatropha biodiesel (B100), high speed diesel (HSD) and their blends (B10 and B20) in single fuel mode and mixture of producer gas and biodiesel blends in dual fuel mode were used to test the combustion characteristics and performance of the diesel engine. The biodiesel used in this study was prepared by a two step 'acid-base' process; acid-pretreatment followed by main base-transesterification reaction; using methanol as reagent and $\mathrm{H} 2 \mathrm{SO} 4$ and $\mathrm{KOH}$ as catalysts for acid and base reactions, respectively. Then the fuel properties of prepared biodiesel and its blends with HSD namely specific gravity, viscosity $\left(\mathrm{mm}^{2} / \mathrm{s}\right)$, calorific value (MJ/ $\mathrm{kg}$ ), flash point $\left({ }^{\circ} \mathrm{C}\right)$, were determined following the American standards and are summarized in Table 2.

A single throat downdraft gasifier $\left(12.5 \mathrm{Nm}^{3} / \mathrm{h}\right)$ available in the Renewable Energy Laboratory, IIT Kharagpur was used to produce the producer gas required to run the engine in dual fuel mode. Briquettes produced from Jatropha seed cake were used as feed material for running the gasifier. The gasifier has cooling and cleaning units which conditioned the gas and made it suitable for feeding into the engine. The volumetric compositions of the producer gas were determined in the gas chromatograph. Table 3 shows the properties of producer gas from gasification of Jatropha seed cake.

Table 3

Producer gas properties

$\begin{array}{lc}\text { Constituents of gas and fuel properties } & \text { Values } \\ \text { Methane (\%, by vol.) } & 1.8 \\ \text { Carbon dioxide ((\%, by vol.) } & 12 \\ \text { Carbon monoxide ((\%, by vol.) } & 20 \\ \text { Hydrogen ((\%, by vol.) } & 15 \\ \text { Nitrogen ((\%, by vol.) } & 50 \\ \text { Density }\left(\mathrm{kg} / \mathrm{m}^{3}\right) & 0.764 \\ \text { Lower calorific value }(\mathrm{MJ} / \mathrm{kg}) & 4.3\end{array}$

\section{Experimental results and discussion}

\subsection{Combustion parameters}

\subsubsection{Ignition delay}

The ignition delay period in a compression ignition engine is a very important performance parameter that influences subsequent combustion processes, engine performance and exhaust emissions. The ignition delay in a diesel engine is defined as the time interval between the start of fuel injection and the commencement of rapid energy release due to combustion. The variations of ignition delay with system load for different fuels in single and dual fuel mode of operation in a diesel engine is shown in Fig. 2. For all the fuel tested ignition delay decreased with increase in system load. Increasing the load increased the residual gas and wall temperature which resulted in a higher charge temperature at injection and hence decrease in the ignition delay. Ignition delay decreased with increase in concentration of biodiesel in biodiesel blends with diesel as shown in Fig. 2. This was mainly due to the shortening of the physical delay and also the high cetane number of biodiesel. The oxygen present in the fuel increased the air fuel mixing rate which reduces the physical delay and higher cetane number of fuel 
started the ignition earlier. In dual fuel mode of operating an engine, the admission of a gaseous fuel with the air influenced profoundly both the physical and chemical ignition processes of the mixture. Its induction would bring about variations in the physical properties of the mixture such as the specific heat ratio and heat transfer parameters. These could lead to significant changes in the charge temperature and pressure levels at the time of fuel injection and extend the physical ignition delay period of the mixture. In dual fuel mode ignition delay was highest for DPG followed by B10PG, $\mathrm{B} 20 \mathrm{PG}$ and B100PG. The advance of ignition performance for producer gas-biodiesel is thought to be the effect of fuel properties such as higher oxygen content and lower stoichiometric air requirement (Yoon \& Lee 2011).

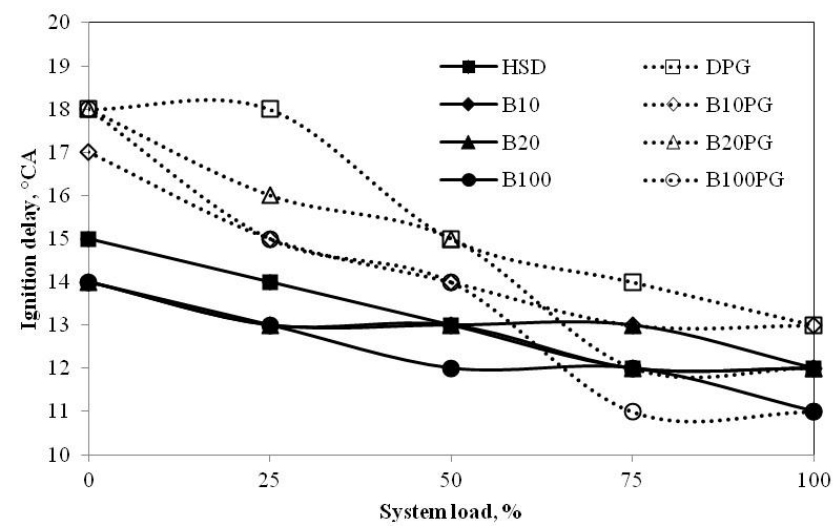

Fig. 2 Effect of system load on ignition delay for different modes of operation.

\subsubsection{Cylinder pressure}

Figure 3 shows the variations of cylinder pressure with crank angle for diesel, neat Jatropha biodiesel and its blends (B10 and B20) in single fuel mode and producer gas and biodiesel in dual fuel mode at 1500 rpm and full load of the engine.

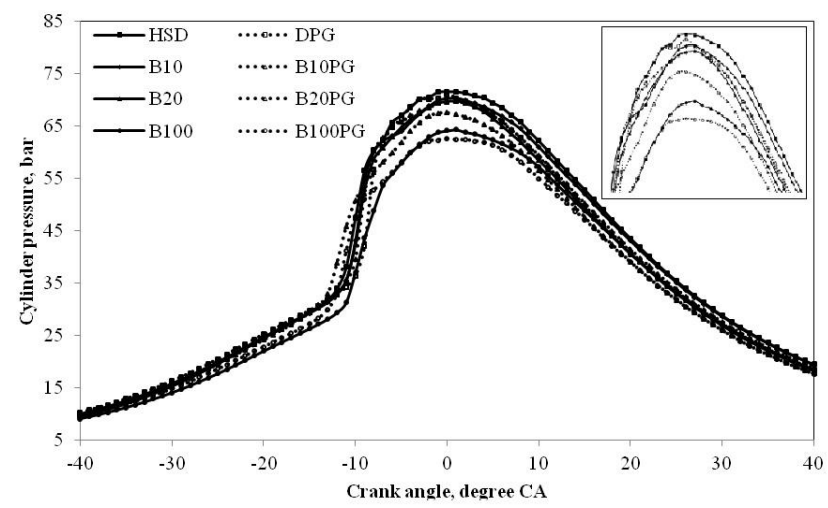

Fig. 3 Variations of cylinder gas pressure with respect to crank angle and fuel type at full load.
From this figure, it is clear that in single fuel mode, the peak cylinder pressure was decreased with the increase of biodiesel addition in the blends. This low combustion performance was caused by lower heating value of biodiesel. When compared to single fuel combustion, the ignition delay was prolonged, and the peak combustion pressure for dual fuel combustions were lowered. The combustion process of the test fuels was similar, consisting of a phase of premixed combustion followed by a phase of diffusion combustion. Premixed combustion phase was controlled by the ignition delay period and spray envelope of the injected fuel. The viscosity and volatility of the fuel had important role to increase atomization rate and to improve air fuel mixing formation. Because of the high viscosity and low volatility of Jatropha biodiesel and its blends, the cylinder peak pressure for these fuels was lower than that of standard diesel. The peak pressure was observed to be 71.261, 70.371, 69.764, 64.355, 70.337, 69.816, 67.571 and 62.531 bar for standard diesel, B10, B20, B100, DPG, B10PG, B20PG and B100PG, respectively. Similar conclusions were drawn by other authors in the literature (Senthil et al. 2005, Canacki et al. 2009, Devan \& Mahalakshmi 2009, and Noureddini \& Zhu 1997). The combustion process of a dual-fuel engine was more complex than that of single-fuel. Prior to ignition of the pilot fuel, the gaseous fuel-air mixture underwent pre-ignition chemical reactions during the relatively long compression stroke. These preignition reactions resulted in the formation of active radicals and partial combustion products those were believed to affect the ignition of the injected pilot fuel (Karim 1983).

The variation of peak cylinder pressure with load for HSD, Jatropha biodiesel and its blends are compared in Fig. 4. It can be seen in this figure that the peak cylinder pressure increased with engine load for all the fuel tested. Since the quantity of fuel burned increased with engine load, it caused an increase in the heat energy released which resulted in an increase in peak cylinder pressure with load.

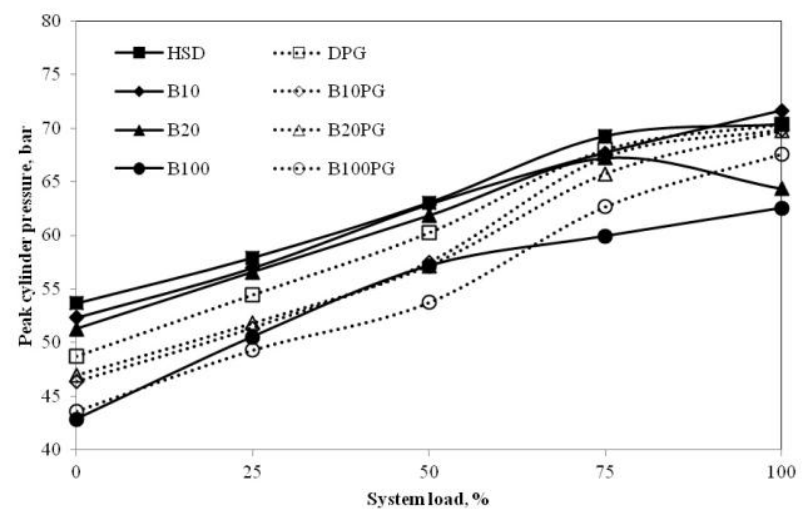

Fig. 4 Effect of system load on peak cylinder pressure for different modes of operation. 


\subsubsection{Heat release rate (HRR)}

The HRR is used to identify the start of combustion, the fraction of fuel burned in the premixed mode, and differences in combustion rates of fuels. Figure 5 shows HRR indicating that the ignition delay for B100 and its blends was shorter than that for diesel in single fuel mode of operation. The maximum heat release rate for standard diesel, B10, B20 and B100 was 156.094, 122.702, 96.606 and $66.976 \mathrm{~J} /{ }^{\circ} \mathrm{CA}$, respectively. This was because of the shorter ignition delay; the premix combustion phase for neat Jatropha biodiesel and its blends was less intense. On the other hand, increased accumulation of fuel during the relatively longer delay period resulted in higher rate of heat release while running with diesel. For B10, B20 blends, the heat release peak was higher than that of B100 due to reduced viscosity and better spray formation. In dual fuel combustion, the rate of heat release was lower compared to single fuel combustion and it decreased with increase in biodiesel blends. The gaseous fuel with the intake-air charge brought about a decrease and dilution of oxygen concentration, a decrease of charge air temperature at the time of starting pilot injection due to the lower polytropic index of producer gas and the pre-ignition reactions of the producer gas-air residual gas mixtures during the intake and compression processes. These principal factors might have caused ignition delay to extend (Phan \& Kanit 2007).

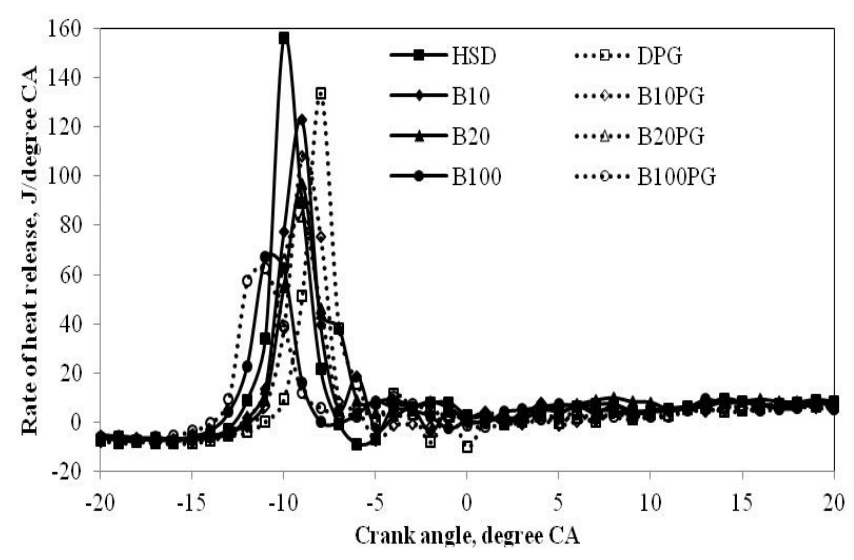

Fig. 5 Variations of heat release rate with crank angle at full load of the engine for different fuels.

\subsection{Performance characteristics}

\subsubsection{Brake specific energy consumption (BSEC)}

To compare the two fuels having different calorific values and density, the term BSEC was preferred over brake specific fuel consumption. BSEC of the engine decreased with increase in the engine load for all the fuels tested as evident from Fig. 6. This was due to the higher percentage increase in brake power with increase in engine load as compared to the increase in fuel consumption due to relatively less heat losses at higher engine loads. Brake specific energy consumption in dual fuel mode (bio-diesel and producer gas) was calculated from the fuel consumption and calorific value of bio-diesel and producer gas. Brake specific energy consumption in dual fuel mode was higher than that of single fuel mode at all load conditions and it increased with increase in fuel blends with HSD.

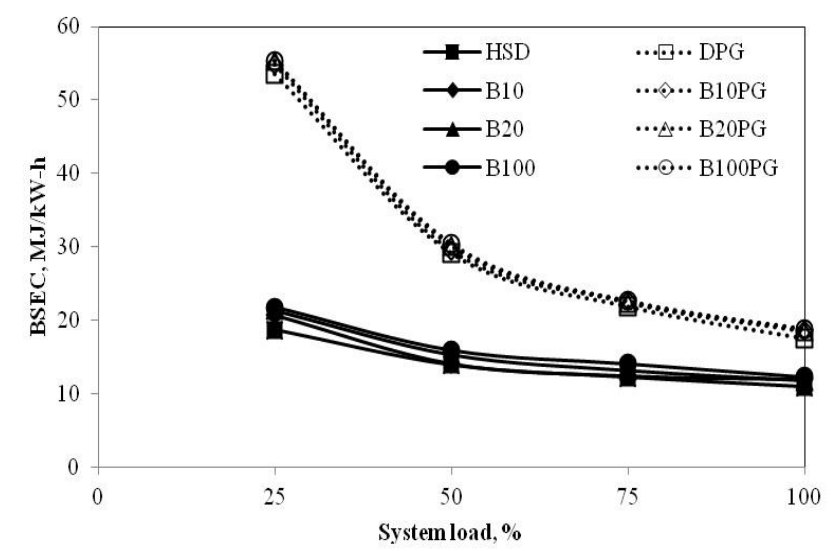

Fig. 6 Variation of BSEC with system load for different modes of operation.

\subsubsection{Brake thermal efficiency (BTE)}

BTE of the engine increased with increase in the engine load for all the fuels tested as evident from Fig. 7. The improved BTE at higher load was due to the reduction in friction loss and increase in brake power with increase in percent load.

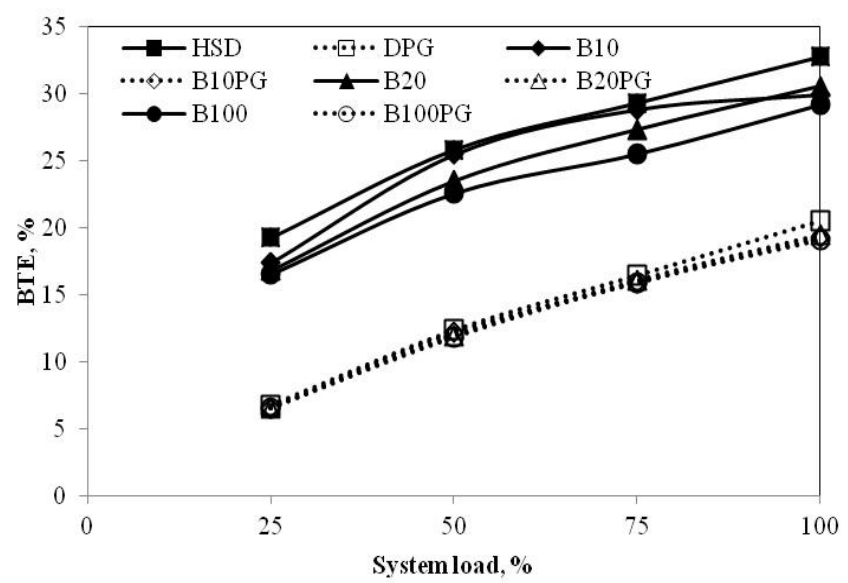

Fig. 7 Variation of BTE with system load for different modes of operation.

Though the presence of inbuilt oxygen improved the combustion of biodiesel, the BTE in general decreased with increasing proportion of biodiesel in the fuel blends with HSD. With increase in biodiesel concentration in fuel blends there is increase in viscosity which causes poor atomization, poor mixture formation and hence poor combustion. A considerable reduction in brake thermal efficiency was observed in dual fuel mode as compared to single fuel mode at all loading conditions. This was due to the effect of lower 
calorific value of producer gas, combusted residual gases, low combustible temperature, and higher total fuel flow rate during combustion process. Also the reduction in BTE might be due to decreased flame propagation speed and increased negative compression work (Yoon \& Lee 2011).

\subsubsection{Exhaust gas temperature (EGT)}

Figure 8 shows the variations of EGT with system load for diesel, JB and their blends. It can be seen from this figure that EGT increased with increase in engine load but decreased with increase in biodiesel concentration in the blends with diesel. The increase in EGT with engine load was mainly due to increase in the amount of energy released at higher loads because of the burning of increased amount of fuel which was injected to meet the extra power requirement to take up the additional loading; hence more heat rejection to the exhaust gases. The decrease in EGT for JB might be due to the poor combustion characteristics of the Jatropha biodiesel and its blends because of its viscosity variation. EGT in dual fuel mode was higher than that of single fuel mode at all load conditions. This might be due to the excess of energy supplied to the engine in dual fuel mode (Banapurmath 2008).

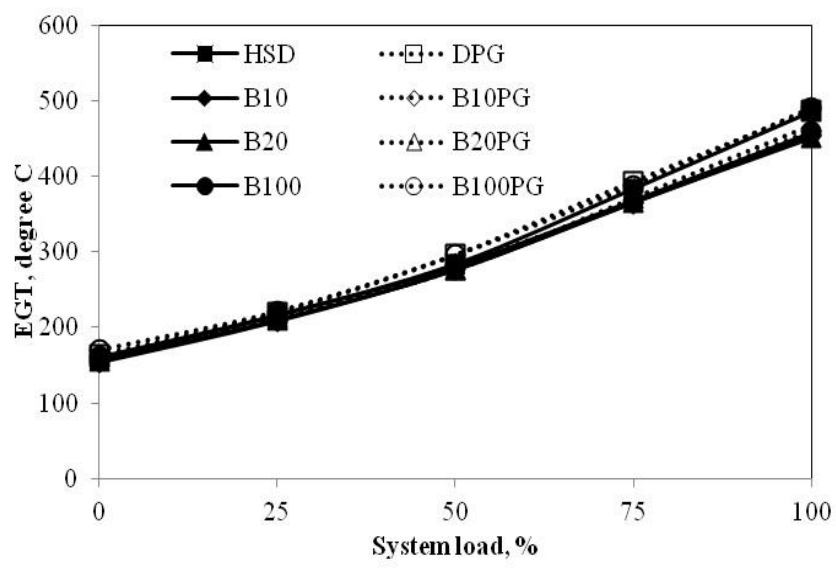

Fig. 8 Variation of EGT with load for different modes of operation.

\subsection{Emission characteristics}

\subsubsection{Carbon monoxide (CO)}

It can be seen from Fig. 9 that CO initially decreased with increase in engine load and then it increased with further increase in engine load for all the fuels tested. Initially, at lower engine loadings, cylinder temperature might be too low, which increased with engine loading due to higher quantity of heat release during the burning of higher quantity of fuel injected inside the cylinder. The increased cylinder temperature at higher engine loads prompted relatively better burning of the fuel resulting in decreased CO. However, with further increase in engine load beyond $80 \%$, CO emission increased due to incomplete combustion of the excess fuel injected into the combustion chamber owing to lower air-fuel ratio which might have prevented oxidation of $\mathrm{CO}$ into $\mathrm{CO}_{2}$. It was observed that the emission of $\mathrm{CO}$ decreased with increasing proportion of jatropha biodiesel in the fuel blends. This was due to the presence of more inbuilt oxygen in the blends with higher biodiesel concentration, which led to relatively better combustion of the fuel resulting in lower $\mathrm{CO}$ emission. Further much higher values of $\mathrm{CO}$ emission were recorded in dual fuel mode as compared to single fuel mode. The higher concentration of $\mathrm{CO}$ emission in the dual fuel mode gave an indication of incomplete combustion. The mixture of high temperature PG and air flow to the engine reduced the amount of oxygen required for complete combustion. This created incomplete combustion and increased $\mathrm{CO}$ emission. Higher CO emission in dual fuel mode operation could be due to combination of factors such as low heating value of gas, low adiabatic flame temperatures, and low mean effective pressures.

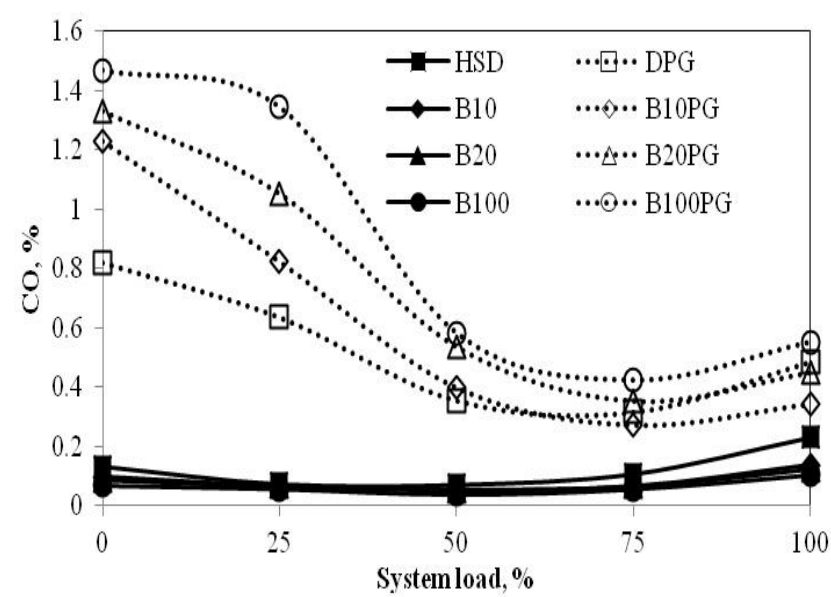

Fig. 9 Variation of CO emissions with system load for different modes of operation.

\subsubsection{Carbon dioxide $\left(\mathrm{CO}_{2}\right)$}

Emission of $\mathrm{CO}_{2}$ is greatly affected by engine loadings as evident from Fig. 10.

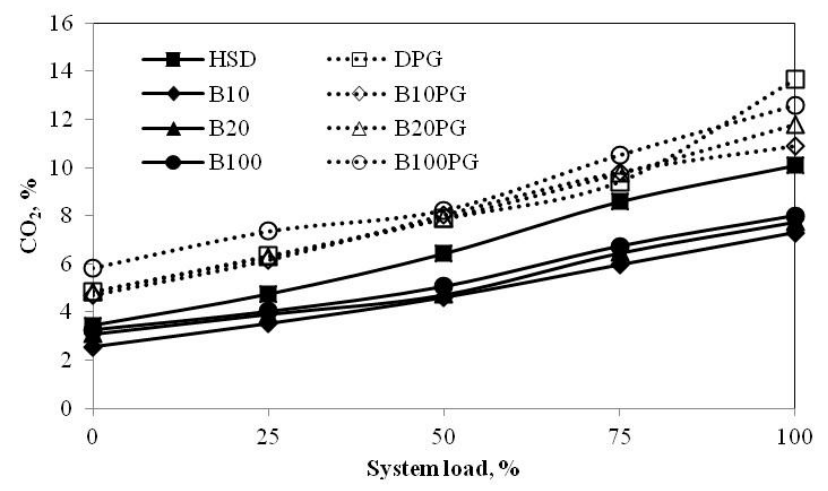

Fig. 10 Variation of $\mathrm{CO}_{2}$ emissions with system load for different modes of operation. 
It can be seen from this figure that the $\mathrm{CO}_{2}$ emission in general increased with increase in engine load. As the amount of fuel injected into the combustion chamber increased with engine load, quantity of fuel going through complete combustion also increased which resulted in increase in cylinder temperature. At elevated temperature, performance of the engine improved with relatively better burning of the fuel resulting in higher $\mathrm{CO}_{2}$ emission. The $\mathrm{CO}_{2}$ emission in general was found to be increased significantly with increase in concentration of biodiesel in the fuel blends at any engine load tested. This could be attributed to the increase in the mass of fuel injected into the combustion chamber for biodiesel blends and better combustion of the injected fuel owing to the inherent oxygen present in the jatropha biodiesel. It can be seen from Fig. 10 that $\mathrm{CO}_{2}$ emission in dual fuel mode was higher than that of diesel mode at all load conditions and it increased with increase in fuel blends with HSD. The reason of increasing $\mathrm{CO}_{2}$ is that the producer gas is a mixture of $\mathrm{CO}, \mathrm{HC}, \mathrm{CH}_{4}$ and $\mathrm{CO}_{2}$. Therefore the combustion in the engine of the producer gas increases the carbon dioxide emission.

\subsubsection{Oxides of nitrogen $\left(\mathrm{NO}_{x}\right)$}

It can be seen from Fig. 11 that the $\mathrm{NO}_{\mathrm{x}}$ concentration in emission increased with increase in engine load for all the fuels tested. As the engine load increased, average gas temperature in the combustion chamber also increased as a result of increased heat energy liberation from the fuel. This led to higher $\mathrm{NO}_{\mathrm{x}}$ emissions at higher loads.

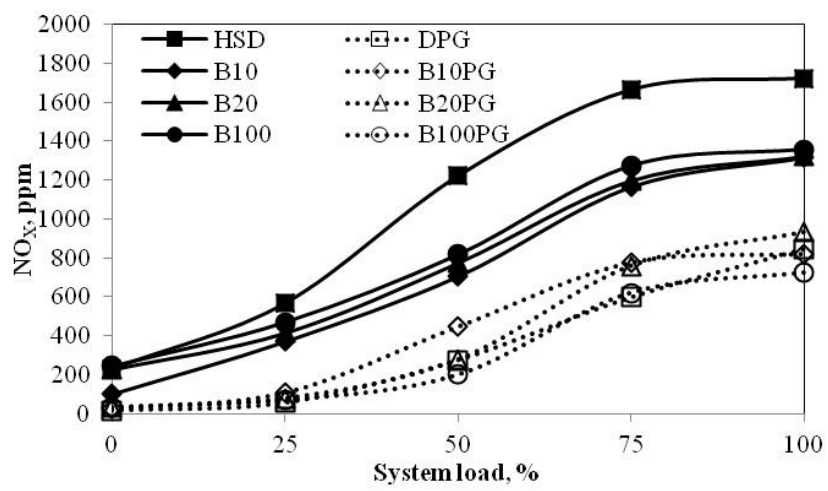

Fig. 11 Variation of NOx emissions with system load for different modes of operation.

The $\mathrm{NO}_{\mathrm{x}}$ emission in dual fuel mode operation was found to be lower than single mode operation. It might be due to the organic nitrogen from air that caused nitrogen dioxide to be formed in diesel mode. The producer gas had no organic nitrogen, it had only atmospheric nitrogen. Further in dual fuel mode $\mathrm{NO}_{\mathrm{x}}$ emission decreased with increase in concentration of biodiesel in fuel blends. This was because with increase in concentration of biodiesel in fuel blends, amount of inbuilt oxygen increased which helped in combustion and decreased in $\mathrm{NO}_{\mathrm{x}}$ concentration in emission.

\subsubsection{Hydrocarbons (HC)}

The variations of $\mathrm{HC}$ with system load for different fuels are given in Fig. 12. It can be observed from Fig. 12 that HC emissions in general increased with increase in engine load. At higher load, the excess fuel required to meet the power requirement resulted in decreased airfuel ratio, consequently increasing the $\mathrm{HC}$ emissions sharply. HC emissions were found to be lower for JB and its blends as compared to HSD over the entire range of engine loads. The reduction in $\mathrm{HC}$ emissions for biodiesel blends might be due to the presence of oxygen content in the biodiesel molecule, which led to a more complete and cleaner combustion. The HC emission in dual fuel mode was found to be higher than single fuel mode at each load and it decreases with increase in biodiesel concentration in fuel blends. This was because in dual fuel mode incomplete combustion led to the formation of more $\mathrm{HC}$ in emissions and with increase in biodiesel concentration in fuel blends increased the inbuilt oxygen which helped in cleaner combustion and hence lowered the amount of $\mathrm{HC}$ in emissions.

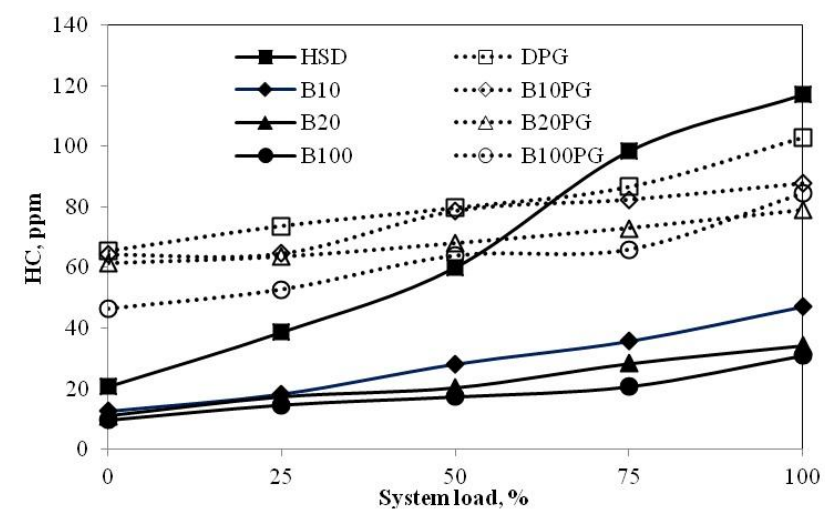

Fig. 12 Variation of HC emissions with system load for different modes of operation.

\section{Conclusion}

Combustion characteristics, performance and emissions of a diesel engine were investigated in a single cylinder DI diesel engine fueled with diesel and biodiesel as pilot fuel with producer gas under various experimental conditions. The following conclusions were drawn from the results:

- The ignition delays of dual-fuel mode operation for both the fuels were longer than for single-fuel mode operation because of the reduction of charge temperature for the gas-air mixture and the high overall specific heat capacity of producer gas. In particular, the ignition delay for biodiesel in single and dual-fuel combustions was slightly shorter than those in HSD under all test conditions, due to the high cetane number, and the oxygen content of biodiesel. 
- The combustion characteristics of single-fuel for biodiesel and diesel have similar combustion pressure and HRR patterns at different engine loads. In dual-fuel mode, the peak pressure and HRR for producer gas-biodiesel dual-fuel were slightly lower than those of producer gas-diesel combustion at full load condition.

- The exhaust gas temperatures were slightly higher for dual-fuel mode of operation compared to single-fuel modes and the differences between the two modes increased at higher engine loads. The higher gas temperature was caused by the excess of energy supplied in the mixed fuel mode.

- At lower system loads (25\% and 50\%), the BSECs for dual-fuel combustion for both fuels were considerably higher than those for single-fuel combustions. At higher loads (over 75\%), the increase of the conversion of producer gas into work led to a large improvement of the BSEC with dual-fuel combustions.

- Significantly lower $\mathrm{NO}_{\mathrm{x}}$ emissions were obtained under the dual fuel mode of operation for both pilot fuels compared to the single-fuel mode under all test conditions, especially HSD.

- The concentrations of HC and CO emissions were considerably higher for the dual-fuel mode with both pilot fuels than those for the single-fuel mode under all test conditions. With the induction of producer gas, the $\mathrm{CO}_{2}$ content of the mixture led to an increase of unburned emissions in dual-fuel combustion. Biodiesel combustion with dual fuel mode yielded higher concentrations of $\mathrm{CO}_{2}$ emissions, because the presence of $\mathrm{CO}$ in producer gas, which oxidized to $\mathrm{CO}_{2}$.

\section{Acknowledgments}

The authors wish to thank Department of Science and Technology (DST), New Delhi, India for providing financial support to carry out the research work.

\section{References}

Alfuso, S., Auriemma, M., Police, G. \& Prati, M.V. (1993) The effect of methyl ester of rapeseed oil on combustion and emissions of DI engines. SAE - 932801.

Raheman, H. \& Phadatare, A.G. (2004) Diesel engine emissions and performance from blends of karanja methyl ester and diesel. Biomass and Bioenergy, 27 (4): 393-397

Usta, N. (2005) An experimental study on performance and exhaust emissions of a diesel engine fuelled with tobacco seed oil methyl ester. Energy Conversion and Management, 46: 2373-2386.

Deshmukh, S.J. \& Bhuyar L.B. (2009) Transesterified Hingan (Balanites) oil as a fuel for compression ignition engine. Biomass and Bioenergy, 33: 108-112

Buyukkay, E. (2010) Effects of biodiesel on a DI diesel engine performance, emission and combustion characteristics. Fuel, 89: 3099-3105

Banapurmath, N.R., Tewari, P.G. \& Hosmath, R.S. (2008) Experimental investigations of a four-stroke single cylinder direct injection diesel engine operated on dual fuel mode with producer gas as inducted fuel and Honge oil and its methyl ester (HOME) as injected fuels. Renewable Energy, 33: 2007-2018

Mustafi, N.N. \& Raine, R.R. (2008) A study of the emissions of a dual fuel engine operating with alternative gaseous fuels. SAE 01-1394 (2008).

Maji, S., Pal, A. \& Aror, B.B. (2008) Use of CNG and diesel in CI engines in dual fuel mode. SAE 28-0072.

Jie, S., Jun, Q. \& Mingfa, Y. (2003). Turbocharged diesel/CNG dual-fuel engines with intercooler: combustion, emissions and performance. SAE 01-3082.

Yoon, S.H. \& Lee, C.S. (2011) Experimental investigation on the combustion and exhaust emission characteristics of biogasbiodiesel dual-fuel combustion in a $\mathrm{CI}$ engine. Fuel Processing Technology, 92: 992-1000

Heywood, J.B. (1988) Internal Combustion Engine Fundamentals, McGraw-Hill Book Co.

Senthil, K.M., Kerihuel, A., Bellettre, J. \& Tazerout, M. (2005) Experimental investigations on the use of preheated animal fat as fuel in a compression ignition engine. Renewable Energy, 30: 2314-2323

Canakci, M., Ozsezen, A.N. \& Turkcan, A. (2009) Combustion analysis of preheated crude sunflower oil in an IDI diesel engine. Biomass and Bioenergy, 33 (5): 760-767

Devan, P.K. \& Mahalakshmi, N.V. (2009) Study of the performance, emission and combustion characteristics of a diesel engine using poon oil-based fuels. Fuel Processing Technology, 90 (4): 513-519

Noureddini, H. \& Zhu, D. (1997) Kinetics of transesterification of soybean oil. J Am Oil Chem Soc, 74: 1457-1463

Karim, G.A. (1983) The dual fuel engine of the compression ignition type-prospects, problems and solutions - a review, SAE - 831073

Phan, M.D. \& Kanit, W. (2007) Study on biogas premixed charge diesel dual fuelled engine. Energy Conversion and Management, 48: 2286-2308 